\title{
The role of sulforaphane on duchenne muscular dystrophy by activation of Nrf2
}

\author{
Cheng-Cao Sun ${ }^{1}$, Jing-Yu Pan ${ }^{1}$, Shu-Jun $\mathrm{Li}^{1,2}$ and De-Jia $\mathrm{Li}^{{ }^{* 1}}$ \\ ${ }^{1}$ Department of Occupational and Environmental Health, School of Public Health, Wuhan University, 430071 Wuhan, P. R. China \\ ${ }^{2}$ Wuhan Hospital for the Prevention and Treatment of Occupational Diseases, 430071 Wuhan, P. R. China
}

\begin{abstract}
Sulforaphane (SFN) possesses powerful chemo-preventive effects and plays a crucial role on oxidative stress and inflammatory. In our recent study, SFN treatment could relieve muscular dystrophy in $m d x$ mice by activating Nrf2 (NF-E2 related factor 2). Moreover, our findings indicated that SFN-activated Nrf2 alleviated muscle inflammation in dystrophin-deficient $m d x$ mice through suppressing NF- $\kappa$ B signaling pathway. Collectively, SFN-induced Nrf2 molecular pathway might be a promising approach for treatment of the patients with Duchenne muscular dystrophy.
\end{abstract}

Abbreviations: DMD: Duchenne muscular dystrophy; SFN: Sulforaphane; Nrf2: nuclear factor erythroid 2-related factor 2 ; HO1: heme oxygenase-1; ARE: antioxidant response element; NQO1: NADH/NADPH quinone oxidoreductase 1

Duchenne muscular dystrophy (DMD) is the most common type of muscular dystrophy, which is also regarded as a severe muscle disease with an incidence of 1 in 3,500 live male newborns in the world [1-3]. The leading cause is dyctrophin gene mutations, which lose regulation of the muscle protein [4]. Cell death, progressive damage of muscle fibers, oxidative stress, and inflammation are the remarkable characteristics of DMD in humans and $m d x$ mice [5]. Glucocorticoid play a role on boosting muscle function and strength in a short time in DMD therapy, but it is not effective and with plentiful side effects, like hypertension, diabetes, mood/behavioral affection for a long time using [6-8]. Therefore, there is not noticeably effective method for treatment of DMD yet.

Nrf2 (NF-E2 related factor 2) is one of the momentous transcription factors, which exists in biological body and affect genes expression of numerous oxidative stress proteins, detoxifying enzymes and antioxidant enzymes [9-10]. Investigations show that Nrf2 is a promising protector against oxidative stress via activation of ARE and its downstream HO-1 and NQO1 [11-12]. Nrf2 could also prevent skeletal muscle from exhaustible exercise induced damage in rats via function of an antioxidant [13]. Additionally, some investigations demonstrate that Nrf2 might play a role of on anti-inflammation in a variety of tissues through inhibition of NF- $\mathrm{KB}$ signaling pathway $[11,14]$. Moreover, $\mathrm{Nrf} 2$ is also considered as a guardian in inflammation mediated airway response [15], emphysema [5] and colon cancer [16-17].

Sulforaphane (SFN) is described as glucoraphanin in many vegetables of brassicaceae family, which possesses powerful chemopreventive effects and is a useful isothiocyanate in our daily diet [18]. Increasing evidence shows that SFN attenuates oxidative stress by regulation of Nrf2 [19-20]. Furthermore, early studies indicate that the function of SFN is impacted via various mechanisms, such as inhibition of cell proliferation, promotion of apoptosis and suppression of metastasis and angiogenesis [9, 21-22]. Although it has been demonstrated with chemo preventive function, the underlying efficacy of SFN on DMD has not been estimated yet.

Previous study indicated that SFN pretreatment alleviated liver damage in rats, owing to its powerful anti-oxidative efficay via activation of Nrf2-ARE signaling pathway [23]. In our recent studies, we explored the function of SFN on $m d x$ mice, which are perceived as the perfect animal models for the pathogenesis research of DMD [1]. SFN treatment could promote gastrocnemius mass, myocardial hypertrophy and exercise capacity in $m d x$ mice, meanwhile morphological features and body weight were also improved [24]. Moreover, we found the proteins and mRNAs of phase II detoxifying enzymes NQO1 and HO-1 of the signaling pathway Nrf2/ARE were significantly upregulated after SFN treatment in $m d x$ mice [24-26]. We also found SFN treatment attenuated oxidative stress response and exercise-induced damage by activating Nrf2-ARE molecular pathway in $m d x$ mice [24].

Inflammation is a critical factor that contributes to progressive damage of muscle and oxidative stress in DMD patients [27]. Therefore, it is urgent to investigate a useful approach to therapy inflammation of DMD patients. Many studies have indicated that Nrf2 protects various cells, tissues and organ systems against wide toxic insults and disease pathogenesis [28]. We explored the anti-inflammatory function of SFN on $m d x$ mice, our findings demonstrated that SFN played a pivotal role regarding treatment of inflammation in $m d x$ mice, and improved the syndrome of dystrophic muscles [29]. The phenomenon might be attributed to inflammation relief in dystrophic muscles

Correspondence to: De-Jia Li, No.115 Donghu Road, Wuchang District, Wuhan, P. R. China, Tel: (86)18271470520; Fax: (86)02768778695; E-mail: lodjlwhu@sina.com

Key words: sulforaphane, duchenne muscular dystrophy, Nrf2, inflammation

Received: August 23, 2015; Accepted: September 11, 2015; Published: September 14, 2015 


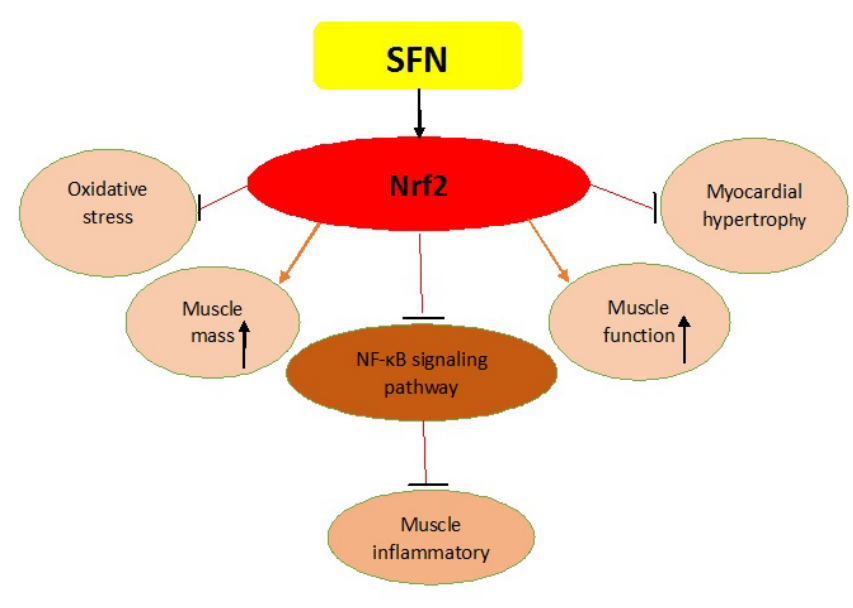

The function of SFN in DMD

Figure 1. The function of Sulforaphane in Duchene muscular dystrophy by activating Nrf2. SFN treatment could promote muscle mass, GAS hypertrophy, myocardial hypertrophy and exercise capacity in mdx mice, and keep dystrophic muscle from oxidative stress damage by activation of Nrf2. Furthermore, SFN had protective effects in muscular inflammation of mdx mice through Nrf2-mediated repression of the NF- $\mathrm{kB}$ signaling pathway.

because we found numbers of immune cells were decreased in aspect of infiltration. Additionally, the levels of proinflammatory cytokines, such as IL-6, IL-1, TNF- $\alpha$, and inflammatory cytokine CD45 were remarkably decreased and the potential mechanism might through repression of the NF- $\kappa B$ signaling pathway, which showed that the SFN had protective effects in muscular inflammation of $m d x$ mice through Nrf2-mediated repression of NF- $\kappa B$ signaling pathway [29-32].

Taken together, SFN plays a crucial role on oxidative stress and chemopreventive effect, which could attenuate muscular dystrophy in $m d x$ mice by activating Nrf2. Moreover, our findings indicated that SFN-induced Nrf2 alleviated muscle inflammation in dystrophindeficient $m d x$ mice through suppression of NF- $\kappa B$ molecular pathway. Then we conclude that SFN-induced Nrf2 might be a promising approach for treatment of the patients with DMD. However, whether there is other mechanism or function of SFN in DMD need further investigate.

\section{Acknowledgements}

This work was supported by National Natural Science Foundation of China (No. 81271943) to Dejia Li, and the Fundamental Research Funds for the Central Universities (No. 2015305020202) to Chengcao Sun.

\section{Disclosure of potential conflicts of interest}

The authors disclose no potential conflict of interest.

\section{References}

1. Bulfield G, Siller WG, Wight PA, Moore KJ (1984) X chromosome-linked muscular dystrophy (mdx) in the mouse. Proc Natl Acad Sci U S A 81: 1189-1192. [Crossref]

2. Hoffman EP, Brown RH Jr, Kunkel LM (1987) Dystrophin: the protein product of the Duchenne muscular dystrophy locus. Cell 51:919-28.

3. Govoni A, Magri F, Brajkovic S, Zanetta C, Faravelli I, et al. (2013) Ongoing therapeutic trials and outcome measures for Duchenne muscular dystrophy. Cell Mol Life Sci 70: 4585-4602. [Crossref]

4. Deconinck N, Dan B (2007) Pathophysiology of duchenne muscular dystrophy: current hypotheses. Pediatr Neurol 36: 1-7. [Crossref]
5. Emery AE (1991) Population frequencies of inherited neuromuscular diseases--a world survey. Neuromuscul Disord 1: 19-29. [Crossref]

6. Bushby K, Finkel R, Birnkrant DJ, Case LE, Clemens PR, et al. (2010) Diagnosis and management of Duchenne muscular dystrophy, part 1: diagnosis, and pharmacological and psychosocial management. Lancet Neurol 9: 77-93. [Crossref]

7. Heier CR, Damsker JM, Yu Q, Dillingham BC, Huynh T, et al. (2013) VBP15, a novel anti-inflammatory and membrane-stabilizer, improves muscular dystrophy without side effects. EMBO Mol Med 5: 1569-1585. [Crossref]

8. Kelly HW, Van Natta ML, Covar RA, Tonascia J, Green RP, et al. (2008) Effect of long-term corticosteroid use on bone mineral density in children: a prospective longitudinal assessment in the childhood Asthma Management Program (CAMP) study. Pediatrics 122: e53-61. [Crossref]

9. Li W, Kong AN (2009) Molecular mechanisms of Nrf2-mediated antioxidant response. Mol Carcinog 48: 91-104. [Crossref]

10. Lee JH, Khor TO, Shu L, Su ZY, Fuentes F, et al. (2013) Dietary phytochemicals and cancer prevention: Nrf2 signaling, epigenetics, and cell death mechanisms in blocking cancer initiation and progression. Pharmacol Ther 137: 153-171. [Crossref]

11. Zhu H, Itoh K, Yamamoto M, Zweier JL, Li Y (2005) Role of Nrf2 signaling in regulation of antioxidants and phase 2 enzymes in cardiac fibroblasts: protection against reactive oxygen and nitrogen species-induced cell injury. FEBS Lett 579: 3029-3036. [Crossref]

12. Malaguti M, Angeloni C, Garatachea N, Baldini M, Leoncini E, et al. (2009) Sulforaphane treatment protects skeletal muscle against damage induced by exhaustive exercise in rats. J Appl Physiol (1985) 107: 1028-1036. [Crossref]

13. Zhu H, Jia Z, Strobl JS, Ehrich M, Misra HP, et al.(2008) Potent induction of total cellular and mitochondrial antioxidants and phase 2 enzymes by cruciferous sulforaphane in rat aortic smooth muscle cells: cytoprotection against oxidative and electrophilic stress. Cardiovasc Toxicol 8:115-125. [Crossref]

14. Disatnik MH, Chamberlain JS, Rando TA (2000) Dystrophin mutations predict cellular susceptibility to oxidative stress. Muscle Nerve 23: 784-792. [Crossref]

15. Emery AE (2002) The muscular dystrophies. Lancet 359: 687-695. [Crossref]

16. de Souza CG, Sattler JA, de Assis AM, Rech A, Perry ML, et al. (2012) Metabolic effects of sulforaphane oral treatment in streptozotocin-diabetic rats. J Med Food 15: 795-801. [Crossref]

17. Juge N, Mithen RF, Traka M (2007) Molecular basis for chemoprevention by sulforaphane: a comprehensive review. Cell Mol Life Sci 64: 1105-1127. [Crossref]

18. Jeong WS, Keum YS, Chen C, Jain MR, Shen G, et al. (2005) Differential expression and stability of endogenous nuclear factor E2-related factor 2 (Nrf2) by natural chemopreventive compounds in HepG2 human hepatoma cells. J Biochem Mol Biol 38:167-76. [Crossref]

19. Scharf G, Prustomersky S, Knasmuller S, Schulte-Hermann R, Huber WW (2003) Enhancement of glutathione and g-glutamylcysteine synthetase, the rate limiting enzyme of glutathione synthesis, by chemoprotective plant-derived food and beverage components in the human hepatoma cell line HepG2. Nutr Cancer 45: 74-83. [Crossref]

20. Scharf G, Prustomersky S, Knasmuller S, Schulte-Hermann R, Huber WW (2003) Enhancement of glutathione and g-glutamylcysteine synthetase, the rate limiting enzyme of glutathione synthesis, by chemoprotective plantderived food and beverage components in the human hepatoma cell line HepG2. Nutr Cancer 45:74-83. [Crossref]

21. Cheung KL, Kong AN (2010) Molecular targets of dietary phenethyl isothiocyanate and sulforaphane for cancer chemoprevention. AAPS J 12: 87-97. [Crossref]

22. Clarke JD, Dashwood RH, Ho E (2008) Multi-targeted prevention of cancer by sulforaphane. Cancer Lett 269: 291-304. [Crossref]

23. Zhao HD, Zhang F, Shen G, Li YB, Li YH, et al. (2010) Sulforaphane protects liver injury induced by intestinal ischemia reperfusion through Nrf2-ARE pathway. World $J$ Gastroenterol 16: 3002-3010. [Crossref]

24. Sun C, Yang C, Xue R, Li S, Zhang T, et al. (2015) Sulforaphane alleviates muscular dystrophy in mdx mice by activation of Nrf2. J Appl Physiol (1985) 118: 224-237. [Crossref]

25. Li Y, Zhang T, Korkaya H, Liu S, Lee HF, et al. (2010) Sulforaphane, a dietary component of broccoli/broccoli sprouts, inhibits breast cancer stem cells. Clin Cancer Res 16: 2580-2590. [Crossref] 
26. Aires A, Mota VR, Saavedra MJ, Rosa EA, Bennett RN (2009) The antimicrobial effects of glucosinolates and their respective enzymatic hydrolysis products on bacteria isolated from the human intestinal tract. J Appl Microbiol 106: 2086-2095. [Crossref]

27. Matsumura K, Ohlendieck K, Ionasescu VV, Tomé FM, Nonaka I, et al. (1993) The role of the dystrophin-glycoprotein complex in the molecular pathogenesis of muscular dystrophies. Neuromuscul Disord 3: 533-535. [Crossref]

28. Lee JM, Li J, Johnson DA, Stein TD, Kraft AD, et al. (2005) Nrf2, a multi-organ protector? FASEB J 19: 1061-1066. [Crossref]

29. Sun CC, Li SJ, Yang CL, Xue RL, Xi YY, et al. (2015) Sulforaphane Attenuates Muscle Inflammation in Dystrophin-deficient mdx Mice via NF-E2-related Factor 2 (Nrf2)-mediated Inhibition of NF-ÎB Signaling Pathway. J Biol Chem 290: 1778417795. [Crossref]
30. Nguyen T, Yang CS, Pickett CB (2004) The pathways and molecular mechanisms regulating Nrf2 activation in response to chemical stress. Free Radic Biol Med 37 433-441. [Crossref]

31. Bonnesen C, Eggleston IM, Hayes JD (2001) Dietary indoles and isothiocyanates that are generated from cruciferous vegetables can both stimulate apoptosis and confer protection against DNA damage in human colon cell lines. Cancer Res 61: 6120-6130. [Crossref]

32. Jeong WS, Keum YS, Chen C, Jain MR, Shen G, et al. (2005) Differential expression and stability of endogenous nuclear factor E2-related factor 2 (Nrf2) by natural chemopreventive compounds in HepG2 human hepatoma cells. J Biochem Mol Biol 38: 167-176. [Crossref]

Copyright: (C2015 Sun CC. This is an open-access article distributed under the terms of the Creative Commons Attribution License, which permits unrestricted use, distribution, and reproduction in any medium, provided the original author and source are credited. 